\title{
The Effect Of Using Atomic Models Interactive Multimedia Flash Based On Students Learning Outcomes
}

\author{
Sihaqqul Firdaus A. H \\ Chemistry Department \\ Universitas Negeri Surabaya \\ Surabaya, Indonesia
}

\author{
Rusly Hidayah \\ Chemistry Department \\ Universitas Negeri Surabaya \\ Surabaya, Indonesia \\ ruslyhidayah@unesa.ac.id
}

\begin{abstract}
The purpose of this study to determine the effect of using atomic models interactive multimedia flash based on students learning outcomes, student learning outcomes that will be measured is how much the value increases obtained by students and the minimum completeness criteria obtained by students. The trials carried out using the one group pretestposttest design study design. Atomic models interactive multimedia were tested limited to 12 students of class XI MIPA 4 of Senior High School 1 Kamal Bangkalan who had obtained atomic structure material. Based on the results of the study it can be concluded that multimedia developed according to its effectiveness is reviewed based on an increase in $\mathbf{N}$-gain of as much as 0,95 with a high category, and the class completes classically with each student completing individually $\geq 75$. Thus the results of this study indicate the use of multimedia can improve student learning outcomes
\end{abstract}

Keywords-Atomic models interactive multimedia, student learning outcomes, effectiveness.

\section{INTRODUCTION}

Education to develop intellectual intelligence and academic brilliance through education in scientific disciplines. The development of education is inseparable from technological developments because of the sophistication of technology that can improve the quality of education, with the use of the 2013 curriculum. Skills to improve the quality and balance of soft skills and hard skills that complement competency, skills and knowledge competencies.

Atomic structure is the basic ingredient in chemicals but, in terms of its characteristics, atomic structure material is an abstract material, and requires a deep understanding, because this material is still abstract [1], it is necessary to visualize to clarify this material, namely by visualization uses technology, through technological developments the problems of national exam questions for high school also overcome one of them is chemistry, it requires a learning process that can facilitate students in the learning process.

Multimedia learning is basically learning by using media words to draw a learning that is considered [2]. Words can consist of printed words (such as on a text screen) or consist of narration. Images can be statistical images (such as illustrations, graphics, tables, photos and maps) or dynamic / moving images (such as animations, videos or interactive images). Interesting learning is defined as "Inner understanding of the material presented, organizing it mentally into cognitive and coherent structures, and integrating it into relevant knowledge that has been obtained" [2].

Multimedia learning promises great potential in changing the way a person learns, to obtain information, adjust information and so on and provide opportunities for educators to develop learning techniques to produce maximum results. Likewise for students, with multimedia learning objectives will be faster about strategies to get information quickly and efficiently, sources of information no longer focus on text from eye-free books but are wider than that. The growing awareness of the importance of developing multimedia learning must be realized by educators, first approved by technology support.

From the results of the research conducted at Senior High School 1 Kamal Bangkalan It is estimated that $86.67 \%$ of students said the atomic structure material is difficult to learn, also seen from the conditions of the field in SMA 1 Kamal learning in the average class using blackboard and book media, and School aid books are also insufficient for all students in the class. This is because it involves the development of learning media so that learning still uses blackboards and books, in the opinion of the average student saying that the material of atomic structure is abstract material and many memorizations that try to be understood and more than $80 \%$ of students say how learning methods are always monotonous namely discussion and lecture, $93.33 \%$ of students want to learn to be done using interactive multimedia not only to students, chemistry teachers also strongly agree if learning is done using interactive multimedia.

Based on this background, the researcher will conduct a study entitled "Development of Atomic Model Interactive Media Flash Based on Atomic Structure Material". With the existence of interactive media can increase the motivation of students to learn and facilitate the material delivered by the teacher, and can be a medium of learning that can help teachers explain the material.

\section{METHOD}

In this research, the trials carried out using the one group pretest-posttest design study design, namely before students using atomic models will be given the pretest questions about the atomic structure and after using atomic models will be given a posttest question about the atomic structure. This is explained as follows:

$\mathrm{O}_{1} \times \mathrm{O}_{2}$ 
Note:

$\mathrm{O}_{1}$ : Pretest value (before being given learning using atomic models interactive multimedia )

$\mathrm{O}_{2}$ : Posttest value (after being given learning using atomic models interactive multimedia )

$\mathrm{X}$ : Learning using atomic models interactive multimedia [3].

The research subjects used were 12 students of class XI MIPA Senior High School 1 Kamal, Bangkalan. These twelve students were selected based on the level of ability of students from high, medium and low. Students who participate in the limited trial phase are students who have obtained atomic structure material. The learning outcomes of students are done by analyzing the value of the pretest and posttest to find out an increase in learning outcomes with ngain and knowing the completeness of learning outcomes. Previously the value data of students tested normality first to determine the data obtained had been normally distributed. The normality test was carried out using SPSS version 16.0 with the Kolmogorov-Smirnov test which showed that the data obtained were normally distributed with $\alpha \geq 0.05$

To calculate the gain (increase), use the normal gain formula [4], which is as follows.

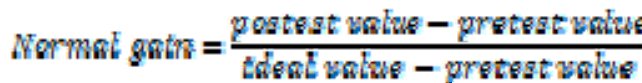

Based on the results of the calculation of the value of $<\mathrm{g}>$ to determine whether there is an increase in student learning outcomes before and after use of atomic models interactive multimedia are developed using score criteria in the following Table I:

TABLE I. CLASSIFICATION NORMAL GAIN

\begin{tabular}{|c|c|c|}
\hline No & Gain Coefficient & Classification \\
\hline 1. & $\mathrm{~g}<0,3$ & Low \\
\hline 2. & $0,3 \leq \mathrm{g}<0,7$ & Is Being \\
\hline 3. & $\mathrm{~g} \geq 0,7$ & High \\
\hline
\end{tabular}

[5].

In this study, atomic models interactive multimedia flash based can be said to be effective if the results of increased learning tests are measured using the n-gain score $\geq 0.3$ with moderate or high criteria.

The completeness of learning outcomes is obtained from the posttest results on atomic structure material. Test questions in the form of tests of cognitive abilities of students regarding the material of atomic structures, especially in the theory of atomic development. The completeness of student learning outcomes individually is said to be complete in learning if students have reached the minimum graduation criteria or KKM with a value of $\geq 75$ [6]. The value of student learning outcomes is calculated by the following formula:

$$
\text { Value }=\frac{\text { scre abtamed }}{\text { maxtmwon score }} \times 100
$$

After the individual completeness value is obtained, it can be determined the classical completeness value, namely:

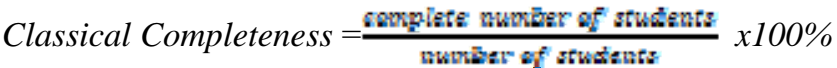

Classes are declared complete classically if $\geq 85 \%$ of students in the class achieve individual completeness [7].

Atomic models interactive media flash based on atomic structure material in this study is said to be effective if the learning outcomes of students are declared complete in a classical manner.

\section{RESULT AND DISCUSSION}

Student learning outcomes are obtained from multiple choice questions given at the pretest and posttest. The assessment at the pretest and posttest was used to determine the improvement of student learning outcomes and the value of students' completeness in the atomic structure material, especially the theory of atom development. Before the results of the pretest and posttest values were calculated using the $\mathrm{N}$-gain formula, the value data of students tested normality first to determine the data obtained had been normally distributed.

Data normality test is a form of testing about normal data distribution. The purpose of this test is to find out whether the data obtained is normally distributed data or not. The purpose of normal distributed data is that data will follow a form of normal distribution where data is centered on average values and media [8].

The normality test is carried out using SPSS Version 16.0 with the Kolmogorov-Smirnov test which shows that the data obtained are normally or abnormally distributed with $\alpha=0.05$. A can be said to be normal if the results

TABLE II. ONE-SAMPLE KOLMOGOROV-SMIRNOV TEST

\begin{tabular}{|c|c|c|c|}
\hline \multicolumn{2}{|c|}{ Kolmogorov-Smirnov Test } & Pretest & Posttest \\
\hline \multicolumn{2}{|l|}{$\mathrm{N}$} & 12 & 12 \\
\hline \multirow{2}{*}{$\begin{array}{l}\text { Normal } \\
\text { Parameters }^{\mathrm{a}}\end{array}$} & Mean & 40.8333 & 97.5000 \\
\hline & Std. Deviation & $1.78164 \mathrm{E} 1$ & 4.52267 \\
\hline \multirow{3}{*}{$\begin{array}{l}\text { Most Extreme } \\
\text { Differences }\end{array}$} & Absolute & .197 & .460 \\
\hline & Positive & .137 & .290 \\
\hline & Negative & -.197 & -.460 \\
\hline \multicolumn{2}{|c|}{ Kolmogorov-Smirnov Z } & .681 & 1.593 \\
\hline
\end{tabular}

obtained are $\alpha \geq 0.05$. Data from SPSS analysis on the results of the pretest and posttest are presented in Table II below.

Based on the table above, the Kolmogorov-Smirnov $\mathrm{Z}$ value obtained at pretest $0.681>0.05$ and at posttest $1.593>$ 0.05 so that it can be seen that the data has been normally distributed, from the results of the analysis stating that the data has normal distribution, then can be calculated N-gain score to determine the increase in learning outcomes from pretest and posttest.

The following is the data from the pretest and posttest obtained from 12 students can be seen in Figure I. 


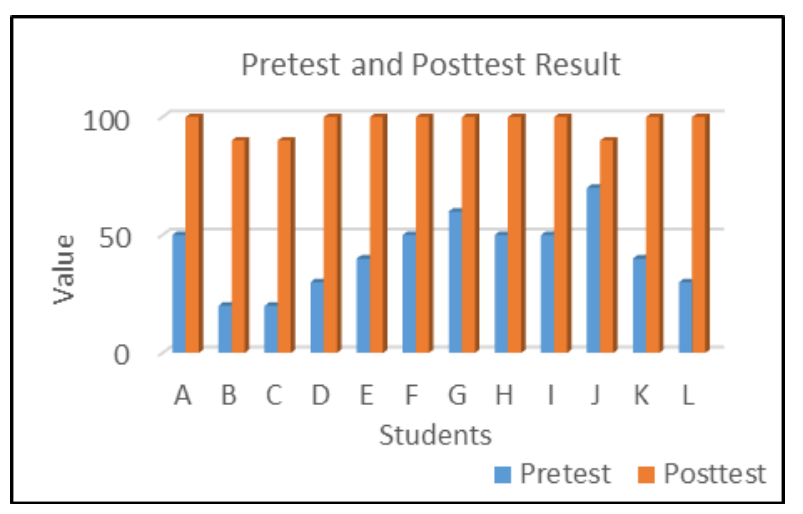

Fig I. Pretest and Posttest Result

Based on the graph above it is known from the data of the pretest results of all students who did not complete which can be interpreted that the value achieved has not reached the specified KKM that is 75 from the obtained values. have understood about the material, from the average value of students who have not yet reached the KKM it can be said that the atomic structure material is classified as difficult but after learning using atomic models interactive multimedia made using the Adobe Flash program and developed with a variety of images, writing, music, and also animation [9], the learning outcomes of all students experienced an increase in accordance with the graphs of learning outcomes, in the posttest and all students completed with a score of $\geq 75$ which means that students complete in classical by $100 \%$. Classes are declared complete classically if $\geq 85 \%$ of students in the class achieve individual completeness [7].

From the value of the students after learning using atomic models multimedia interactive, it can be seen that the value of students is better than before, the atomic structure material that was initially difficult was easily understood after learning using media developed according to David Ausubel's meaningful learning theory, meaningful learning can occur if someone learns by associating a new phenomenon into their knowledge structure [10], and also from dual coding theory one will learn better when the learning media used are the right mix of verbal and non verbal chapters [11]. The following is data about student ngain scores results can be seen in Table III below.

Table III. Student n-gain score results

\begin{tabular}{|c|c|c|c|}
\hline Nu & Student & N-gain score & Criteria \\
\hline 1 & A & 1.00 & High \\
\hline 2 & B & 0.87 & High \\
\hline 3 & C & 0.87 & High \\
\hline 4 & D & 1.00 & High \\
\hline 5 & E & 1.00 & High \\
\hline 6 & F & 1.00 & High \\
\hline 7 & G & 1.00 & High \\
\hline 8 & H & 1.00 & High \\
\hline 9 & I & 1.00 & High \\
\hline 10 & J & 0.67 & Is Being \\
\hline 11 & K & 1.00 & High \\
\hline 12 & L & 1.00 & High \\
\hline
\end{tabular}

From the scores of 12 students obtained from limited trials, $8.33 \%$ increased from learning outcomes with moderate criteria and $91.67 \%$ with high criteria. This medium and high criterion was mapped with medium criteria when the value of n-gain score $(0.3<\mathrm{g}<0.7)$, while for high criteria $g>0.7$ students who were included in the high criteria were also discussed by students who supported in the learning process using interactive multimedia atomic models such as inviting students to listen to teacher discussions on how to encourage media, this can help students in the media related to learning that can be seen from students who learn to improve learning at high participants.

Increased learning outcomes of students when testing is limited to an average with high criteria, only one student in improving learning outcomes gets criteria, improvement with criteria being tested is done by groups using interactive atomic multimedia models but the students still get good results with complete posttest values.

Increased learning outcomes of students at a limited trial get an average n-gain value of 0.95 with high criteria. Computer Technology Research (CTR), states that human memory is affected by $20 \%$ of what is seen, and $30 \%$ of what is heard. Humans can remember $50 \%$ of what is seen and heard, humans can remember $80 \%$ of what is seen, heard, and done at once. Interactive multimedia is able to present information in several forms that can be seen heard and done, so that it can be an effective tool for a teachinglearning process [12]. From the increasing value of students, the use of atomic models interactive multimedia greatly influences student learning outcomes, and is also supported by Viandhika's research in which the development of flashbased interactive multimedia can help students learn [13].

From the value of completeness and improvement in learning outcomes students can be known that interactive multimedia can greatly help students and can be declared effective because they have fulfilled the specified requirements, namely students experience an increase in learning outcomes with a minimum score of $\geq 0.3$ with moderate criteria or a score $\geq 0.7$ with high criteria, and students complete individually $\geq 75$ and complete classically $\geq 85 \%$.

\section{CONCLUSION AND SUGGESTION}

A. Conclusion

Based on the results of data analysis, conclusions can be drawn about atomic models multimedia interactive that are very effective to use and greatly affect the learning outcomes of students, especially in atomic structure material, seen from the learning outcomes of students who state students complete in classics and complete individually and get average scores n-gain value of 0.95 in the high category.

\section{B. Suggestion}

From the research that has been done, it would be better to add student worksheet to complement or support the use of interactive multimedia developed.

\section{REFERENCES}

[1] Chang, Raymond. 2004. Kimia Dasar Konsep-Konsep Inti Edisi Ketiga Jilid 1. Jakarta: Erlangga.

[2] Mayer, R. E. (2005). Cognitive Theory of Multimedia Learning. In R. E. Mayer (Ed.), The Cambridge handbook of multimedia learning (pp.31-48). New York, NY, US: Cambridge University Press. 
[3] Sukmadinata, N. S. 2016. Metode Penelitian Pendidikan. Bandung: PT remaja Rosdakarya.

[4] Arifin, Zainal. 2012. Evaluasi Pembelajaran cetakan keempat. Bandung: PT Remaja Rosdakarya.

[5] Sudjana. 2008. Penilaian Hasil Belajar Mengajar. Bandung: Remaja Rosda Karya.

[6] Kemendikbud. 2017. Panduan Penilaian oleh Pendidik dan Satuan Pendidikan. Jakarta: Kementrian Pendidikan dan Kebudayaan Republik Indonesia.

[7] Agustini, Rudiana, Muchlis, Harun Nasrudin, \& Utiyah Azizah. 2016. Asesmen Buku Pegangan Mahapeserta didik. Yogyakarta: Absolute Media.

[8] Kariadinata, Rahayu. 2012. Dasar-Dasar Statistika Pendidikan. Bandung: Pustaka Setia.
[9] Ariesto, H. 2013. Multimedia Interaktif dengan Flash. Yogyakarta: Graha Ilmu.

[10] Ausubel, David P. 2012. The Use of Advanced Organizersmin the Learning and Retention of Meaningful Verbal Material. Jurnal Of Education Psychology, 51: 267-272.

[11] Arsyad, Azhar. 2016. Media Pembelajaran. Jakarta: Raja Grafindo Persada.

[12] Munir. 2013. Multimedia dan Konsep Aplikasi Dalam Pendidikan. Bandung: Alfabeta.

[13] Viandhika, S Saputro, dan Nugroho. 2015. Pengembangan Multimedia Interaktif Dengan Menggunakan Program Adobe Flash Untuk Pembelajaran Kimia Materi Hidrolisis Garam. Jurnal Pendidikan Kimia Universitas Sebelas Maret, Vol 4 (2). 